Article

\title{
Characterization of Fibrous Mordenite: A First Step for the Evaluation of Its Potential Toxicity
}

\author{
Dario Di Giuseppe ${ }^{1,2}$ (1) \\ 1 Department of Chemical and Geological Sciences, University of Modena and Reggio Emilia, \\ Via G. Campi 103, I-41125 Modena, Italy; dario.digiuseppe@unimore.it \\ 2 Department of Sciences and Methods for Engineering, University of Modena and Reggio Emilia, \\ Via Amendola 2, I-42122 Reggio Emilia, Italy
}

Received: 4 August 2020; Accepted: 28 August 2020; Published: 31 August 2020

\begin{abstract}
In nature, a huge number of unregulated minerals fibers share the same characteristics as asbestos and therefore have potential adverse health effects. However, in addition to asbestos minerals, only fluoro-edenite and erionite are currently classified as toxic/pathogenic agents by the International Agency for Research on Cancer (IARC). Mordenite is one of the most abundant zeolites in nature and commonly occurs with a fibrous crystalline habit. The goal of this paper is to highlight how fibrous mordenite shares several common features with the well-known carcinogenic fibrous erionite. In particular, this study has shown that the morphology, biodurability, and surface characteristics of mordenite fibers are similar to those of erionite and asbestos. These properties make fibrous mordenite potentially toxic and exposure to its fibers can be associated with deadly diseases such as those associated with regulated mineral fibers. Since the presence of fibrous mordenite concerns widespread geological formations, this mineral fiber should be considered dangerous for health and the precautionary approach should be applied when this material is handled. Future in vitro and in vivo tests are necessary to provide further experimental confirmation of the outcome of this work.
\end{abstract}

Keywords: mordenite; mineral fibers; erionite; potential toxicity

\section{Introduction}

Occupational or environmental exposure to mineral dusts is one of the main causes in the development of pneumoconiosis and lung cancer [1]. Among airborne particles, the most notorious toxic/carcinogenic agent is asbestos [1,2]. Asbestos is a generic term which refers to six minerals exploited commercially for their outstanding physical properties, mostly due to their fibrous morphology [3]. Asbestos minerals are chrysotile and amphibole asbestos (i.e., amosite, crocidolite, anthophyllite, tremolite, and actinolite) [2,3]. It is generally recognized that asbestos is a toxic and carcinogenic agent associated with the induction of mesothelioma, lung tumours and other lung diseases [2,4]. Hence, chrysotile and amphibole asbestos have been classified by International Agency for Research on Cancer (IARC) as carcinogenic to humans (Group 1) [2]. Concurrently, starting from the 1980s, many countries imposed a ban on asbestos [5]. Nowadays, asbestos and asbestos containing materials (ACM) are gradually being replaced by safe alternatives for human health such as rock wool and plastic fibers. In recent years, a general concern is growing regarding other mineral fibers that are not classified (or not regulated) as asbestos, but assumed to show the same potential toxicity [4]. The term elongate mineral particles (EMPs) has been coined to include all such mineral fibers [5]. In addition to the six asbestos minerals, the following EMPs have raised global concern: non-regulated fibrous amphibole (e.g., winchite [6,7], richterite [6,7], fluoro-edenite [8], fibrous glaucophane [9]), fibrous antigorite [10], balangeroite [11] and fibrous zeolites (e.g., erionite [12], offretite [13] and ferrierite [14]). Within this context, the case of Turkish fibrous erionite is noteworthy [15]. As provided by long-term 
epidemiological studies and several animal carcinogenicity tests, fibrous erionite is responsible for epidemics of mesothelioma in Cappadocia (Turkey), where villages were built with erionite-bearing rocks $[2,15]$. Recent works highlighted that although there are differences in the crystal chemistry and genetic environment, several fibrous zeolites possess the same chemical-physical properties that are deemed to prompt adverse effects in vivo by fibrous erionite $[13,14,16]$. One of the most common natural fibrous zeolites is mordenite [17,18]. Mordenite is a zeolite with orthorhombic structure (space group $\mathrm{Cmcm})$ and ideal chemical formula $\left(\mathrm{Na}_{2}, \mathrm{~K}_{2}, \mathrm{Ca}\right)\left[\mathrm{Al}_{8} \mathrm{Si}_{40} \mathrm{O}_{96}\right] \cdot 28 \mathrm{H}_{2} \mathrm{O}[19,20]$. The crystal structure of mordenite was determined by Meier [19], while its crystal chemistry was studied extensively by Passaglia [19]. Mordenite displays a framework characterized by edge-sharing 5-member tetrahedral rings of tetrahedral $\left(\mathrm{TO}_{4}\right)$, built up from a combination of 5-1 secondary building units [20-23]. These building units are linked by edge-sharing into chains along $c$, which are in turn linked together by 4-rings to form a puckered sheet perforated with 8-ring holes. A unidimensional pore system, consisting of 12 membered rings of TO4, runs parallel to the [001] direction. The channel wall has side pockets, in the [010] direction, circumscribed by 8-membered rings. Each side pocket connects the 12-ring channel through 8-membered rings with a distorted 8-ring channel running parallel to the [001] direction. Mordenite occurs mainly in tuff deposits (diagenetic origin), as well as, is often found in the voids of volcanic rocks (hydrothermal origin) coexisting with other zeolites (e.g., clinoptilolite, heulandite, stilbite, and scolecite) [24]. In both hydrothermal and diagenetic occurrences, mordenite generally shows a fibrous crystal habit $[24,25]$. Sedimentary deposits of mordenite are present in several countries (e.g., Italy [26], Greece [27], Japan [28], and the United States [14]) where its content is often high enough for mineral exploitation. Rocks containing mordenite are known to have a high cation exchange capacity [24,27]. Consequently, mordenite has been increasingly used in various application areas such as gas separation processes, sorbent and molecular sieve, animal feed supplements and catalytic process [24,27]. Because, a large amount of mordenite fiber can eventually be mined and used for the aforementioned applications, some concerns may raise due to the close resemblance of mordenite with fibrous erionite which is known to be a carcinogenic agent. Currently, mordenite is listed by the IARC in the Group 3 (not classifiable as to its carcinogenicity to humans) [29]. However, as stated in the IARC Monographs Preamble 2019 [30], an evaluation in Group 3 is not a statement of non-carcinogenicity or overall safety. Moreover, as pointed out by the IARC Working Group in the Monographs 68, the main cause of difficulties in the classification of mordenite is the lack of sufficient literature data [29]. Indeed, no data are currently available on the toxicity and pathogenicity of mordenite in exposed humans. At the same time, the number of in vitro investigations and animal carcinogenicity studies related to mordenite are very few if compared to those relating to asbestos or erionite [2,29]. One of the first studies concerning biological activity of mordenite was done by Suzuki [31] who used two naturally occurring erionite and mordenite samples, to test their carcinogenic and fibrogenic effects on mice. The results of this study showed that both the erioniteand mordenite-treated mice developed fibrosis, but the effect was more pronounced in the case of erionite. In a later study by Suzuki et al. [32], a larger group of animals was subjected to intraperitoneal and intra-abdominal injection of mordenite and other mineral fibers types. In the mice exposed to mordenite, no peritoneal tumours were seen at the end of the test (7-23 months after injection), and there were no tumours in other organs. Peritoneal fibrosis was observed; however, in mordenite-treated mice. The fibrogenicity of mordenite was confirmed by the works of Tátrai et al. [33] and Adamis et al. [34]. Overall, the few studies on mordenite found in the literature states that fibrous erionite is more carcinogenic than fibrous mordenite and the health risk associated to this latter is relatively low or null [29].

As a matter of fact, the key factors in toxicity, inflammation and pathogenicity of mineral fibers are $[4,12,35,36]$ : (a) morphology, (b) surface reactivity, and (c) biopersistence.

The length $(\mathrm{L})$ and width $(\mathrm{W})$ of mineral fibers (i.e., the main parameters of fibers morphology) are key factors in toxicity, inflammation and pathogenicity of mineral fibres [37-40], while the curvature of the fibers affects the binding process of proteins and influence cell adhesion [35,41]. According to 
Stanton et al. [37] the optimal morphological parameters of a fiber to induce lung disease are $\mathrm{L}>8 \mu \mathrm{m}$ and $\mathrm{W}<0.25 \mu \mathrm{m}$. The crystal habit of a fiber influences its depositional pathway in the respiratory tract $[35,38,42]$. At same time, the density determines its aerodynamic diameter and therefore it affects the deposition depth of inhaled fibre in the airways [35,43].

Surface reactivity of a mineral fiber is strongly influenced by the iron found at the surface of mineral fibers and the electric charges surrounding the fibres [35,44-47]. Iron promotes the formation of the reactive oxygen species (ROS), with cyto- and genotoxic effects through a Fenton-like chain reaction [35,46-48]. To be active, iron sites must be on the surface of the fiber where they can be in contact with the extracellular or intracellular environment $[35,49]$. The electric charges surrounding the fibers, measured as zeta potential, may correlate with a number of phenomena responsible for adverse effects $[35,50]$.

One of the key parameters in the mineral fiber toxicity is the biopersistence as it influences the capability to induce chronic inflammation and pathogenicity in the lungs $[35,36,38,51,52]$. Biopersistence is the ability of an exogenous particle (such as a mineral fiber) to persist in the human body regardless of chemical dissolution (biodurability) and physical clearance mechanisms [35,36,38,51,52]. Mineral fibers carried by the air can pass the upper respiratory system (the first defence mechanism of the body against alien particles) and settle in the alveolar space where they promote the recruitment of phagocytic cells (e.g., macrophages) in charge of dissolution and clearance of the fibers [35,51,52]. This second defence mechanism of the body against respirable particles is effective for small spherical objects but fails for longer and thinner fibers $[37,38]$. When macrophages fail to completely internalize the longer fibers (i.e., frustrated phagocytosis), an inflammatory activity is prompted [36]. This inflammatory activity become chronic, because fibers can be biopersistent and resist reiterated attempts of phagocytosis [35-40]. Generally, if a mineral fibre rapidly dissolves in the lung (i.e., low biodurability), it is assumed that it has a low biopersistence and is less toxic than a mineral fiber with high biodurability [36,51,52].

The main aim of this study is to verify if fibrous mordenite possesses the above-mentioned "toxicity kay factors". Moreover, to objectively evaluate the hazard associated to the fibrous mordenite respect to the fibrous erionite, these two mineral fibers were compared from the morphological and chemical-physical point of view. Fibrous mordenite from Poona, India, was used as a representative member of fibrous mordenite zeolites. The studied mordenite sample was characterized using a suite of experimental techniques, and its characteristics were compared to those of fibrous erionite described in literature.

\section{Materials and Methods}

\subsection{Mordenite Sample}

The mordenite sample taken into consideration comes from the zeolite collection of the Chemical and Geological Sciences Department of the University of Modena and Reggio Emilia, Italy. This sample was recovered in the suburb of Pashan in the Poona district, Maharashtra, India. It is a hydrothermal origin mordenite and is an orthorhombic silica-rich zeolite. Crystal structure and crystal chemistry of this zeolite were identified and described by Passaglia. [19]. Cell parameters of this mordenite are $a=18.094(4) \AA ; b=20.477(4) \AA ; c=7.520(2) \AA ; V=2786 \AA^{3}$ [19]. Generally, this mineral occurs in the voids of basalt flows belonging to the Deccan Traps. Mordenite crystals are extremely thin, almost capillary size, and either form radiating tufts or tangled woolly adhering to the walls of cavities [53]. Figure 1 shows an image of the sample. The specimen is approximately $3 \mathrm{~cm}$ long and approximately $1 \mathrm{~cm}$ wide. The mordenite fibers form radial fibrous tufts or cotton-like material. Small quartz crystals are perched on the fibers or hidden between them. 


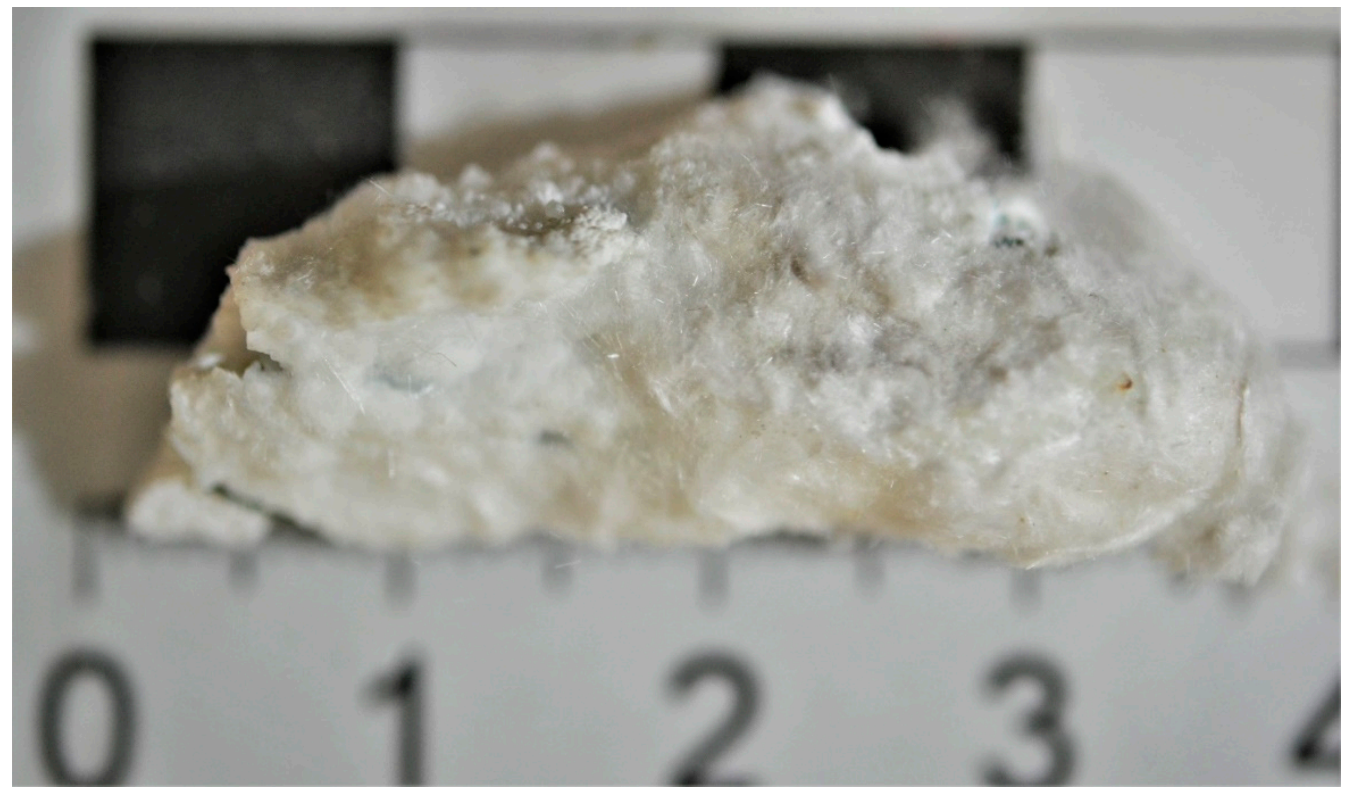

Figure 1. A stereomicroscopic image of the mordenite from Poona district, Maharashtra, India.

\subsection{Electron Microscopy}

Morphological observations were performed using an environmental scanning electron microscope (ESEM) FEI Quanta-200 equipped with energy-dispersive X-ray (EDX) spectrometer Oxford INCA-350 for microchemical analyses. Operating conditions were $15 \mathrm{kV}$ accelerating voltage, $3.5 \mu \mathrm{A}$ beam current $11 \mathrm{~mm}$ working distance and $0^{\circ}$ tilt angle. Small amounts of powder from samples were mixed with $1 \mathrm{~mL}$ of ethanol. A drop of the suspension was laid on a carbon tape mounted on an $\mathrm{Al}$ stub and gold coated (10 nm thick). Images were collected using the signal of secondary electrons. The surface of the samples was investigated, working at different magnification levels, from $1000 \times$ up to $20,000 \times$. The fiber size and morphometric parameters were determined on $~ 100$ individual fibers, using 15 scanning electron microscope (SEM) images. Lengths and diameters were calculated using ImageJ image analysis software, version 1.52a [54].

The chemical composition of the mordenite was obtained by SEM-EDX following the procedure described by Mattioli et al. [13]. SEM-EDX chemical data were acquired using a low counting time to avoid an increase in temperature on the fiber's surface and minimize the migration of alkaline metals [13].

\subsection{Fiber Density and Aerodynamic Diameter}

Theoretical density of the mordenite fibers was obtained using the following formula: (molecular weight $\times$ number of molecules per unit cell)/(volume of unit cell $\times$ Avogadro's number). The density of zeolite it is a fundamental parameter for the calculation of the aerodynamic diameter $\left(D_{a e}\right)$ of its fibers [55]. $D_{a e}$ influences the deposition depth of inhaled particles in the airways [55]. Particles with $D_{a e}>5 \mu \mathrm{m}$ are deposited in the nasal respiratory tract, whereas particle with $3 \leq D_{a e} \leq 15 \mu \mathrm{m}$ are deposited in the lower respiratory tract that extends from the trachea to the lungs $[43,55,56]$, which is the main focus of respiratory diseases [57]. Particles with $D_{a e} \approx 2-3$ and $<0.2$ can easily settle in the alveolar space [55]. $D_{a e}$ can be calculate using the equation by Gonda and Abd El Khalik [58]:

$$
D_{a e}=d \sqrt{\left(\frac{1}{\frac{2}{9}\left(\frac{1}{(\ln 2 \beta-0.5)}\right)+\frac{8}{9}\left(\frac{1}{(\ln 2 \beta+0.5)}\right)}\right)\left(\frac{\rho}{\rho_{0}}\right)}
$$


where $d=$ fiber diameter; $\beta=$ fiber length $/ \mathrm{d}$ (aspect ratio); $\rho=$ density; $\rho_{0}=$ unit density $\left(1 \mathrm{~g} / \mathrm{cm}^{3}\right)$.

\subsection{Determination of the Zeta Potential}

When a solid particle is suspended in a liquid medium, its charged surface is surrounded by ions of opposite sign from the liquid phase $[40,49,50]$. The arrangement of the mobile ions at the solid-liquid interface is called the electrical double layer (EDL). According to the Gouy-Chapman-Stern model [50,59-61], EDL is a thin film of ions with nonzero net charge composed of two layers: the first one is a compact and relatively immobile layer of ions adsorbed to the solid surface (Stern layer); the second is a diffuse layer of mobile ions outside the Stern layer, which penetrates to a certain extent in the liquid phase. The zeta potential is the electrostatic potential at the boundary dividing the two layers [50,59-61]. Knowing the zeta potential of mineral fibers is an important tool for understanding the reactions that may occur at the fiber-living matter interface $[35,55]$. The zeta potential of the mordenite sample was determined using a Zetasizer Nano Series instrument (Malvern, Worcestershire, UK). Analysis were performed using double-distilled water (resistivity of $18.2 \mathrm{M} \Omega . \mathrm{cm}$ ) as dispersants. Measurements were conducted at $\mathrm{pH} 4.5$ and 7 , a temperature of $37^{\circ} \mathrm{C}$ and equilibration time of $120 \mathrm{~s}$. A solution having $\mathrm{pH} 7$ was chosen to reproduce the extracellular environment $[35,60,61]$. Subsequently, the solution was adjusted to $\mathrm{pH} 4.5$ using diluted $\mathrm{HCl}$, to replicate the intracellular chemical environment of the macrophage $[35,60,61]$.

\subsection{Biodurability}

Biodurability of mineral fibers is their ability to resist to the chemical/biochemical alteration [41,44]. Biodurability of the mordenite fibers was determined by dissolutions batch test at $37^{\circ} \mathrm{C}$. Test was conducted by leaching 6 samples $(10 \mathrm{mg})$ of sample into a batch reactor with a water and $\mathrm{HCl}$ solution $(100 \mathrm{~mL})$ at $\mathrm{pH}=4$. The degree of dissolution is determined by measuring the change of the sample mass after different times: $24 \mathrm{~h}, 48 \mathrm{~h}, 1$ week, 2 weeks, 1 month, 2 months, and 3 months. The dissolved mass fraction (Dmf) of the mordenite was calculated using the following equation [62]:

$$
D m f=1-\left(m_{t} / m_{0}\right)
$$

The dissolved mass fraction of the mineral fibers can be used as a useful parameter to identify the relatively biodurability of a fiber. According to the results of the tests carried out by Gualtieri et al. [51,62], during the 90 days of the dissolution test, the Dfm of biodurable fibers (i.e., erionite and amphibole asbestos) never exceeds the threshold of 0.4. In contrast, chrysotile, commonly recognized as a modest biodegradable mineral fiber, shows Dfm values above 0.4 , just two weeks after the start of the dissolution test [51,62].

\section{Results}

A gallery of acquired SEM images of the sample is reported in Figure 2. Mordenite from Poona occurs as very elongated and prismatic crystals with average width $\sim 7 \mu \mathrm{m}$ and length up to $600 \mu \mathrm{m}$. Furthermore, in the sample, acicular and fibrous mordenite crystals with diameters $<1 \mu \mathrm{m}$ are also present, sometimes grouped in bundles of large size. SEM images also showed that mordenite fibers have flat surface, roughly prismatic morphology and a low flexibility. The summary statistics of the geometry of the fibers not grouped in bundles are reported in Table 1. The data display a wide range of length ( $\mathrm{L}$ ) values which ranging from 2.09 to $118 \mu \mathrm{m}$ (average $20.8 \mu \mathrm{m}$ ), but the longer fibers predominate in the population. In fact, more than $75 \%$ of the fibers are longer than $11 \mu \mathrm{m}$. The widths of the fibers range overall between 0.11 and $3.34 \mu \mathrm{m}, 50 \%$ of the fibers show a width of higher than $0.59 \mu \mathrm{m}$. 
a)

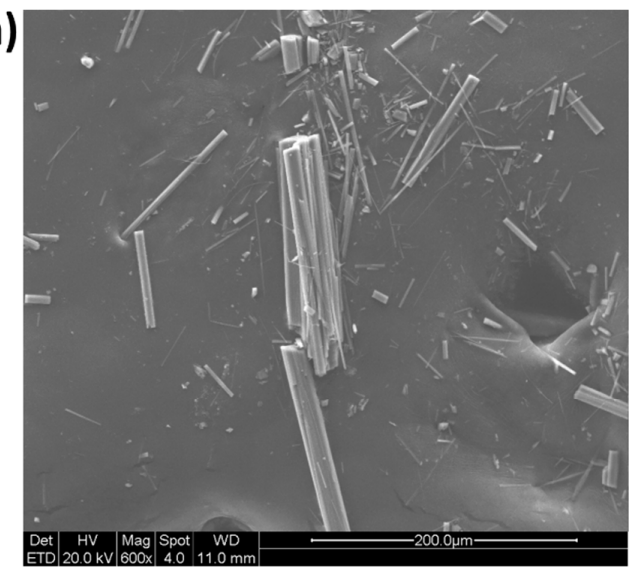

c)

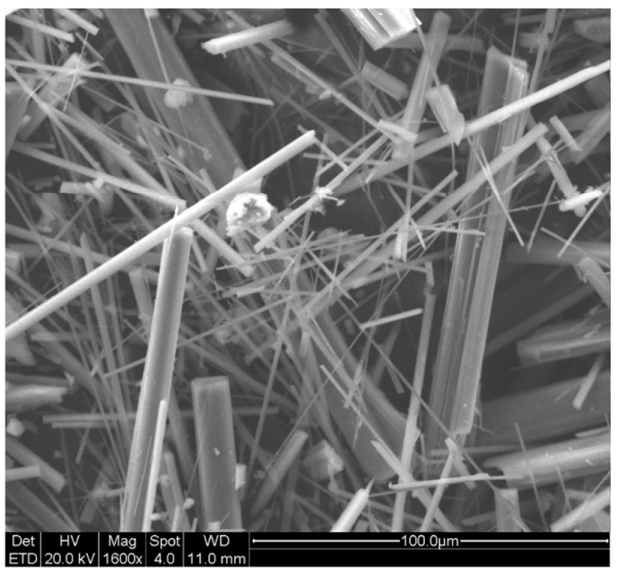

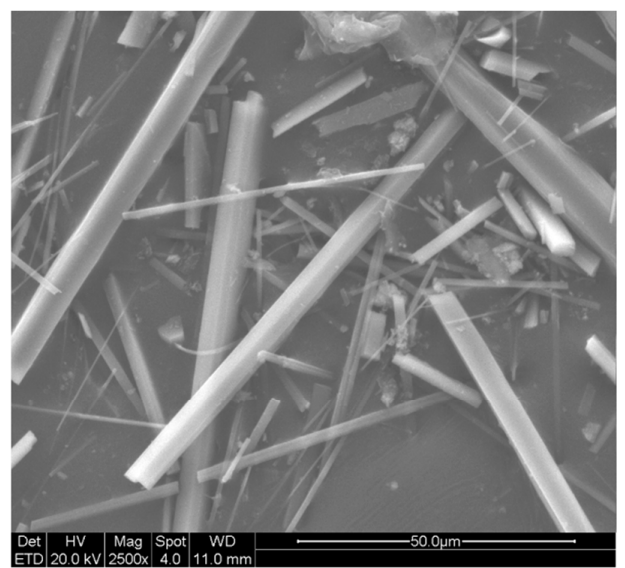

b)

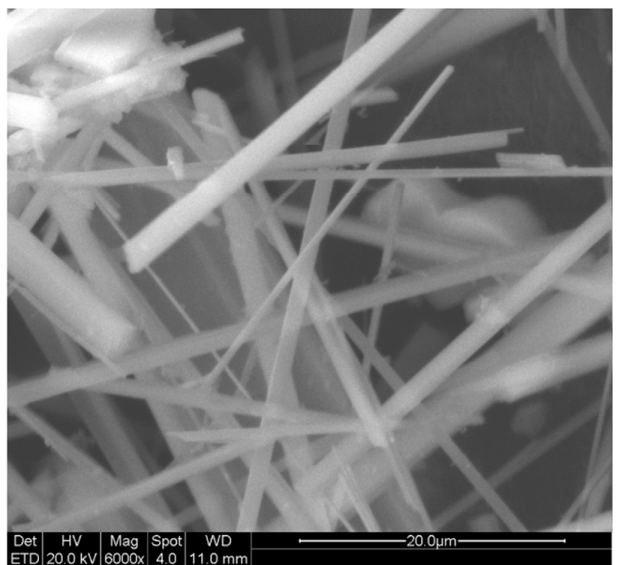

d)

Figure 2. Selected examples of SEM microphotographs of the mordenite samples: $(\mathbf{a}, \mathbf{b})$ general overview of the sample; $(\mathbf{c}, \mathbf{d})$ close-up of very elongated and narrow mordenite crystals.

Table 1. Summary statistic of mordenite fibers geometry. L (length); W (width); Min (minimum); Max (maximum); $\sigma$ (standard deviation). * Percentile is a value below which a given percentage of values in a dataset fall. Example: given a group of observations, the 25 th percentile is the value that is greater or equal to $25 \%$ of the observations, i.e., the $25 \%$ of fibers have $\mathrm{L} \leq 11.2 \mu \mathrm{m}$ and $\mathrm{W} \leq 0.61 \mu \mathrm{m}$.

\begin{tabular}{ccccccccc}
\hline \multicolumn{7}{c}{ Percentiles * } \\
\hline & Min & 5th & 25th & 50th & 75th & 95th & Max & б \\
\hline $\mathrm{L}(\mu \mathrm{m})$ & 2.09 & 3.52 & 11.2 & 20.8 & 36.7 & 56.1 & 118 & 20.5 \\
$\mathrm{W}(\mu \mathrm{m})$ & 0.11 & 0.18 & 0.61 & 0.95 & 1.24 & 1.80 & 3.34 & 0.58 \\
\hline
\end{tabular}

According to the World Health Organization (WHO) guidelines, mineral fibers of respirable size with relevant biological activity (so-called "critical" fibers) are those equal to or longer than $5 \mu \mathrm{m}$ and having diameters up to $3 \mu \mathrm{m}$, with a length/width ratio (aspect ratio) $\geq 3: 1$ [63]. 75\% of the 200 observed fibers fit the WHO counting criteria concerning width and only $10 \%$ of the fibers are shorter than the length value set by the WHO. All of the investigated fibers showed an aspect ratio $>3$.

As reported by Mattioli et al. [64], erionite fibers can exhibit two main morphologies. Fibrous erionite may occur with the typical "woolly" aspect, i.e., a thin and flexible fibrous habit that looks the same as wool. The fiber length may exceed $200 \mu \mathrm{m}$ and the width ranging from 0.5 to $3 \mu \mathrm{m}$ [64]. The fibers of the second type are acicular with diameter of $2-5 \mu \mathrm{m}$ and lengths up to $30 \mu \mathrm{m}$ [64]. They are generally grouped together in bundles up to $100 \mu \mathrm{m}$ in length and variable width. As is the case for the mordenite, even the erionite bundles have great tendency to separate into straight and quite rigid thin fibrils (average diameter $0.5 \mu \mathrm{m}$ ) [64]. 
Applying the Equation (1) to a representative Poona mordenite fiber with theoretical density $\rho=2.11 / \mathrm{cm}^{3}$, mean length $20.8 \mu \mathrm{m}$ and average diameter $(\mathrm{d})=0.95 \mu \mathrm{m}$, the obtained Dae is $2.63 \mu \mathrm{m}$. Accordingly, it can be assumed that the mordenite fibers of the studied sample can easily penetrate through the respiratory tract and settle in the alveolar space [55]. Data concerning the aerodynamic diameter of erionite fibers are not available in the literature. However, since erionite is considered a positive carcinogen, its fibers are assumed to be classified as breathable/inhalable.

The results of the EDX analyses expressed as a percentage by weight with standard deviations are shown in Table 2. The data were obtained by averaging several point-analyses carried out on ten distinct mordenite crystals. Because EDX analyses of fibrous zeolite may be subject to critical errors, two criteria were adopted to assess the reliability of the data. Sum of the $\mathrm{Si}+\mathrm{Al}$ atoms (47.79) close to the half of the oxygen atoms (48); total balance errors $\mathrm{E}=\left[\left(\mathrm{Al}-\mathrm{Al}_{\text {theor. }}\right) / \mathrm{Al}_{\text {theor. }}\right] \times 100$ lower than $10 \%$, where $\mathrm{Al}_{\text {theor. }}=(\mathrm{Na}+\mathrm{K})+2(\mathrm{Ca}+\mathrm{Mg})$.

Table 2. Elemental composition of Poona mordenite and erionite from Nevada and Karain [64]. * Chemical data are renormalized using a theoretical water content of $14.0 \mathrm{wt} \%$. Standard deviation in brackets.

\begin{tabular}{cccc}
\hline $\mathbf{w t} \%$ & $\begin{array}{c}\text { Mordenite } \\
\text { Poona (India) }\end{array}$ & $\begin{array}{c}\text { Erionite } \\
\text { Nevada (USA) }\end{array}$ & $\begin{array}{c}\text { Erionite } \\
\text { Karain (Turkey) }\end{array}$ \\
\hline $\mathrm{SiO}_{2}$ & $68.82(1.57)$ & $58.47(0.35)$ & $56.66(0.32)$ \\
$\mathrm{Al}_{2} \mathrm{O}_{3}$ & $10.35(0.92)$ & $14.30(0.21)$ & $13.63(0.27)$ \\
$\mathrm{Fe}_{2} \mathrm{O}_{3}$ & $0.20(0.03)$ & $0.13(0.05)$ & $0.07(0.04)$ \\
$\mathrm{MgO}$ & $0.08(0.01)$ & $0.48(0.12)$ & $0.02(0.10)$ \\
$\mathrm{CaO}$ & $2.95(0.59)$ & $3.35(0.23)$ & $1.85(0.10)$ \\
$\mathrm{Na} 2 \mathrm{O}$ & $3.17(0.98)$ & $0.80(0.10)$ & $2.48(0.16)$ \\
$\mathrm{K}_{2} \mathrm{O}$ & $0.21(0.09)$ & $4.17(0.29)$ & $5.49(0.45)$ \\
$\mathrm{H}_{2} \mathrm{O}$ & $14.0 *$ & $18.46(0.45)$ & $19.60(0.42)$ \\
$\mathrm{Tot}$ & $99.98(1.84)$ & 81.54 & 80.40 \\
\hline
\end{tabular}

The chemical formula of mordenite from Poona, as determined from EDX spot analyses is:

$$
\left(\mathrm{Na}_{3.63} \mathrm{~K}_{0.16} \mathrm{Ca}_{1.87} \mathrm{Mg}_{0.07}\right)\left[\mathrm{Al}_{7.21} \mathrm{Si}_{40.67} \mathrm{O}_{96}\right] 28 \mathrm{H}_{2} \mathrm{O}
$$

The unit formula was calculated on the basis of 96 oxygens. The $\mathrm{Fe}_{2} \mathrm{O}_{3}$ content was considered not incorporated in the zeolite. In Table 2, the chemical composition of fibrous erionite from Nevada (USA) and Karain (Turkey) is reported for comparison [64]. The mordenite has a content of tetrahedral atoms $[\mathrm{Si} /(\mathrm{Si}+\mathrm{Al})=0.85]$ within the known range of this mineral species $(0.80-0.85)$. The $\mathrm{Si} / \mathrm{Al}$ ratio of Poona mordenite (5.64) is significantly higher that the erionite from Nevada and Karain (3.47 and 3.52, respectively). The non-framework cation composition of mordenite is mostly Na-dominant, whereas, $\mathrm{K}$ is the dominant extra-framework cation in the structure of erionite samples.

The total Fe content is one of the most important factors for the fiber-induced patho-biological activity $[35,48]$. As far as erionite is concerned, several studies confirming the absence of iron in the structure of erionite [65-68]. Generally, iron is associated with iron-rich impurities (oxides, hydroxides or sulphates) present as particles or nanoparticles coating the surface of the erionite fibers [66]. Regarding mordenite, our investigations supporting the hypothesis that the $\mathrm{Fe}_{2} \mathrm{O}_{3}$ content as incorporated in the extra-zeolite phases. SEM micrographs and relative EDX analysis on the Poona mordenite sample revealing the presence of iron-rich particles at the surface of the fibers. Figure 3 displays a close-up of the fibers surface. On fibers surface, small particles and clusters, were observed. Relative EDX analysis showed that such particles are enriched in iron with respect to the bulk (Figure 4). 

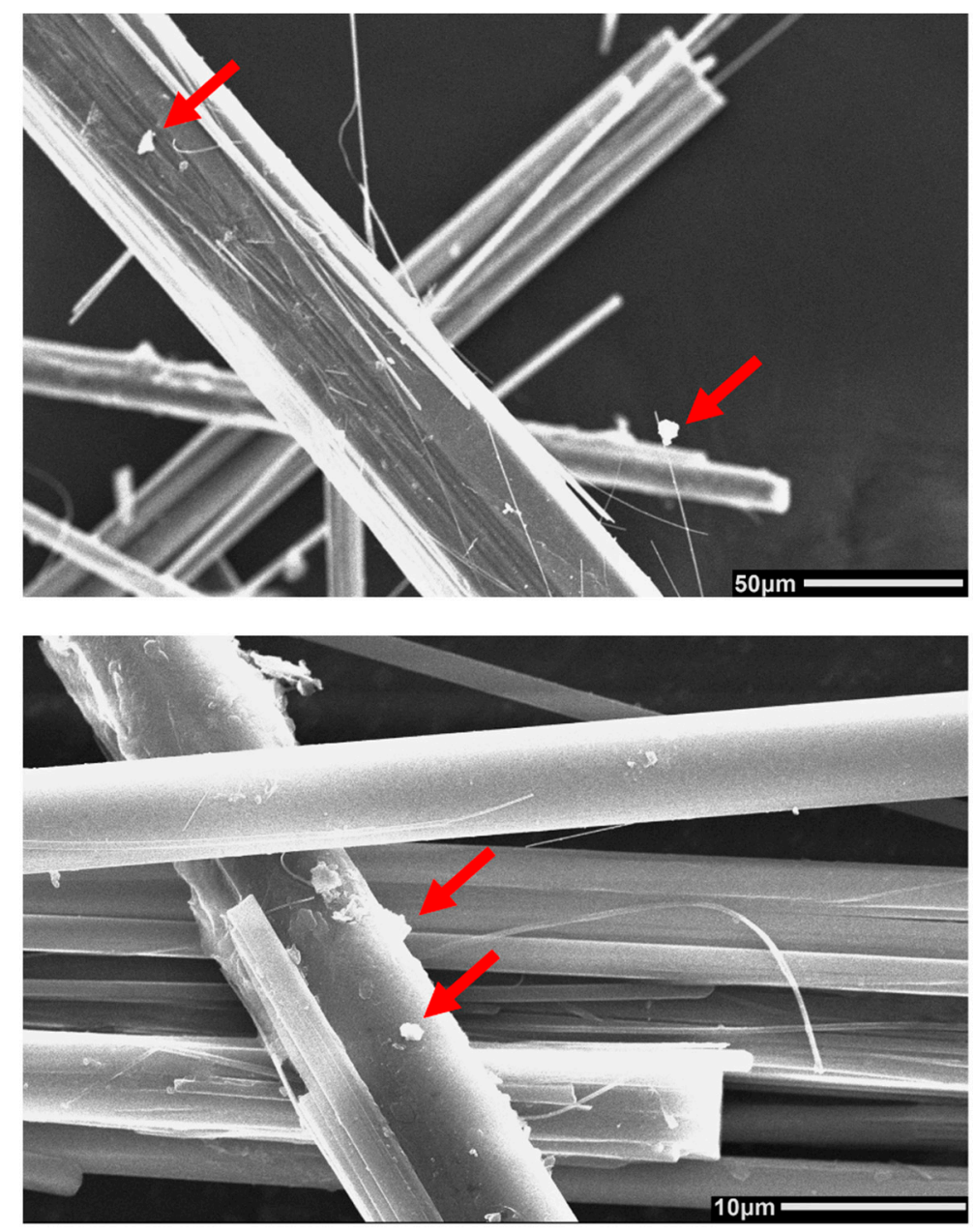

Figure 3. SEM images of mordenite fibers. Both images show mordenite fibers and particles on their surface (maybe hematite or goethite [65]). Some particles are pointed out with red arrows.

The zeta potential of fibrous zeolites was studied in depth by Pollastri et al. [50] and Gualtieri et al [16]. When double distilled water is chosen as the dispersion medium, the zeolite fibers show negative values of the zeta potential. According to the zeta potential model applied to zeolites [50], the presence of extra-framework cations determines a positive charge of the Stern layer, and a resulting attraction of negatively charged molecules to form the diffused corona. Consequently, the zeta potential will have negative values. The zeta potential of mordenite fibres under intracellular conditions (i.e., at $\mathrm{pH} 4.5$ ) displays values in the range -10 to $-20 \mathrm{mV}$; while in extracellular conditions (i.e., at $\mathrm{pH} 7.0$ ) the values are in the range between -25 and $-35 \mathrm{mV}$. These values are in agreement with those measured for erionite [50].

The raw dissolution curve of the investigated fibrous mordenite is reported in Figure 5. For comparison, the dissolution curves of UICC standard chrysotile and of fibrous erionite-Na from Jersey (Nevada, USA) is reported [62]. Chrysotile asbestos can be considered a representative member of mineral fibers with low biodurability [51,52,62], while erionite is considered a mineral fiber with high biodurability [51,62]. As showed in the Figure 5, the difference in the dissolution time of fibrous mordenite and erionite with respect to chrysotile asbestos is striking. After about $4000 \mathrm{~h}$, the UICC chrysotile is completely dissolved and its Dmf value is greater than 0.8. Otherwise, after the same time interval, the $\mathrm{Dmf}$ of mordenite and erionite is lower than the threshold values of 0.4. 

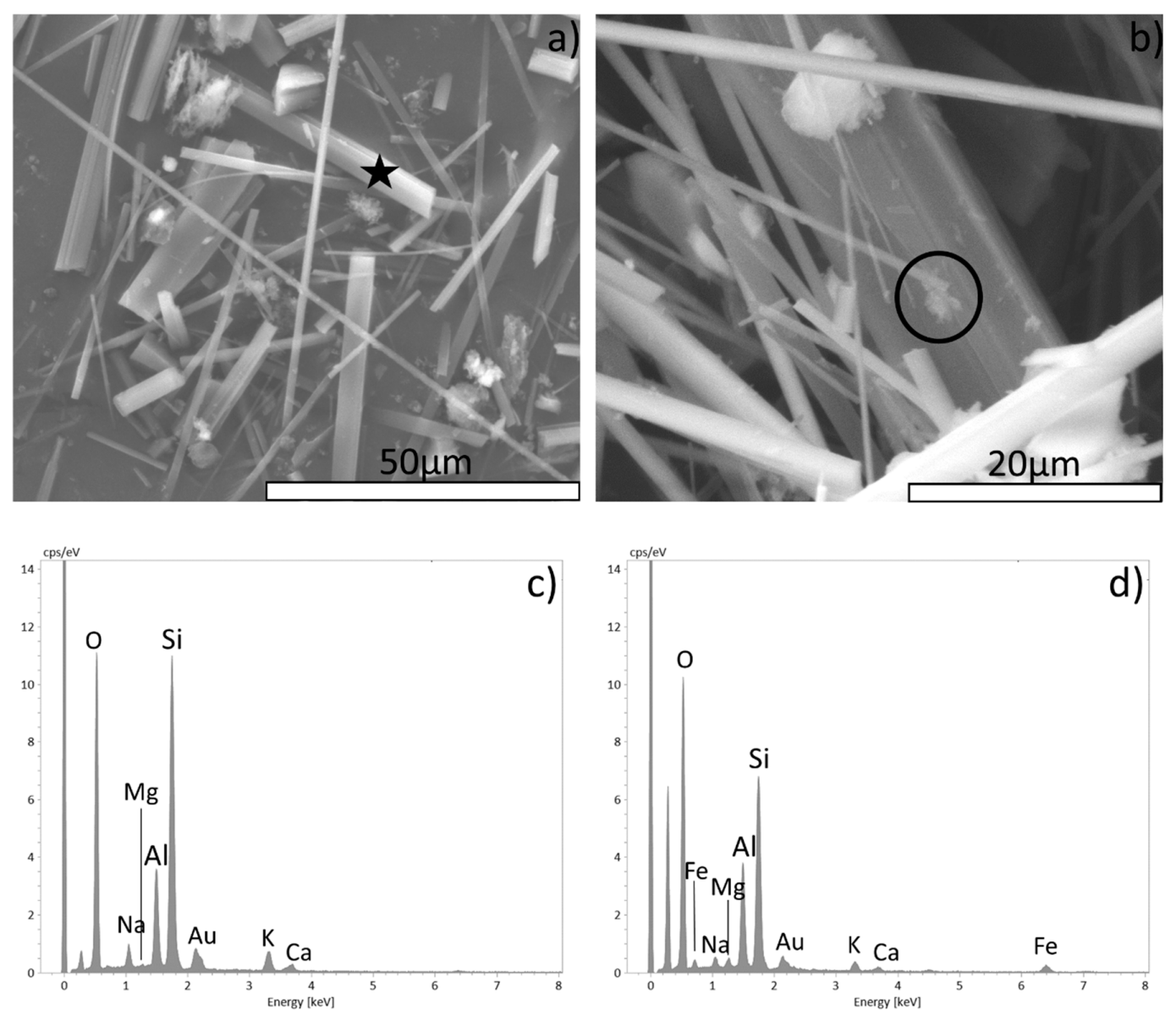

c)

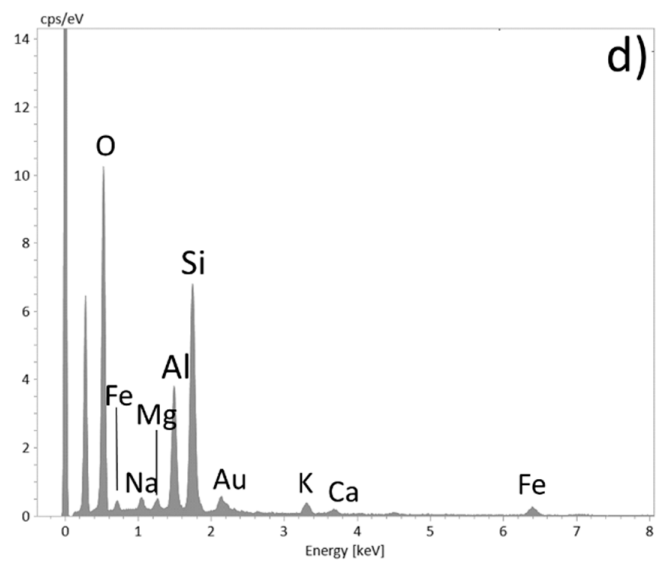

Figure 4. Gallery of SEM pictures and relative EDX spot analyses of the Poona sample. (a) Poona sample with acicular mordenite crystals: (b) Poona mordenite with microparticles enriched in iron present at the surface of the fibers. (c) Typical EDX spectrum recorded on mordenite surface free from the particles. No iron was found. (d) Representative EDX spectrum of the microparticles present in the fibers surface. A peak produced by iron is observed.

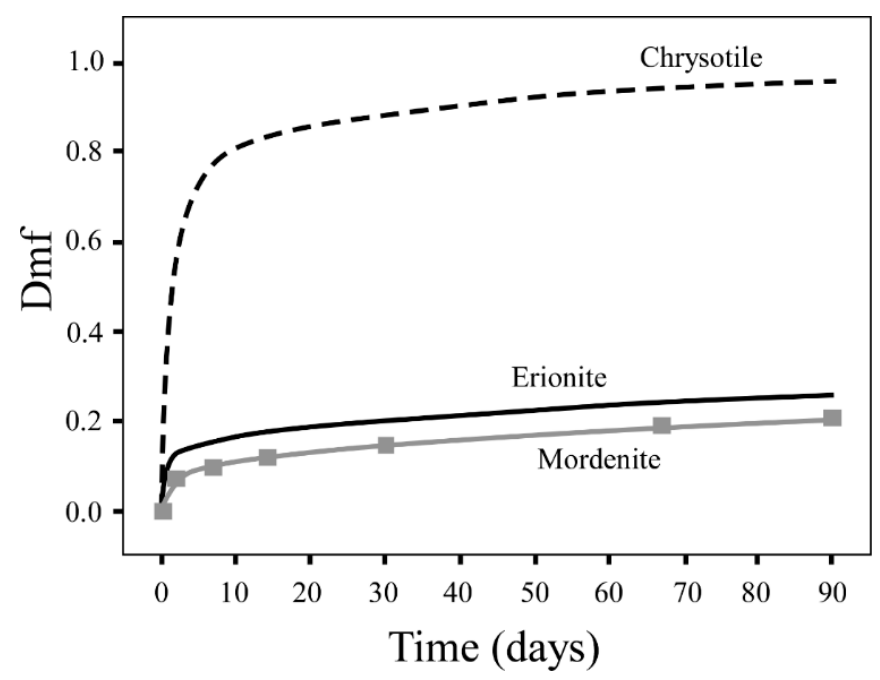

Figure 5. The raw dissolution curves of Poona mordenite. Trend of raw dissolution curves of chrysotile and fibrous erionite were reported for comparison [62]. 


\section{Discussion}

Despite the considerable efforts of the scientific community in the last decades, to date, a conclusive model explaining the toxicity mechanisms of asbestos has not been provided. Nevertheless, currently investigations based on in vitro and in vivo models suggested that a crucial role in the pathogenesis asbestos-related is played by the morphology of the fibers [35-38]. Chrysotile, asbestos amphibole, and fibrous erionite are known to possess the well-known "asbestos-like" habit, i.e., these minerals grow in a fibrous aggregate of curled, flexible, cylindrical, long, and thin crystals that readily separate. On the contrary, most of the Poona mordenite crystals have a stocky shape or acicular habit and null or low flexibility. However, in this context it is important to underline that natural mordenite zeolite group show a wide range of crystal habit. In particular, the diagenetic mordenite often has a morphology that resembles asbestos. Figure 6 shown a gallery of SEM image of mordenite from Ponza Island (Italy) [26] and Lovelock (Nevada, USA) [14]. Both mordenite samples occur in diagenetically altered rhyolitic rocks. Ponza mordenite occurs as an aggregate of very thin fibers that forms a "brush" texture (Figure 6a,b). Individual fibers have a slight degree of flexibility, W less than $0.5 \mu \mathrm{m}$ and $\mathrm{L}$ in the range of 10-15 $\mu \mathrm{m}$. Lovelock mordenite fibers appear with a fibrous crystal habit and its fibers have $\mathrm{L} \approx 9 \mu \mathrm{m}$ and $\mathrm{W}$ below $0.6 \mu \mathrm{m}$ (Figure 6c,d).

a)

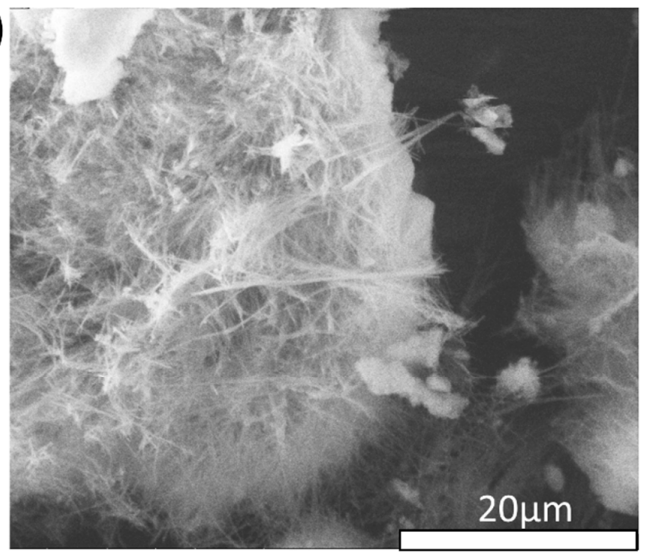

c)

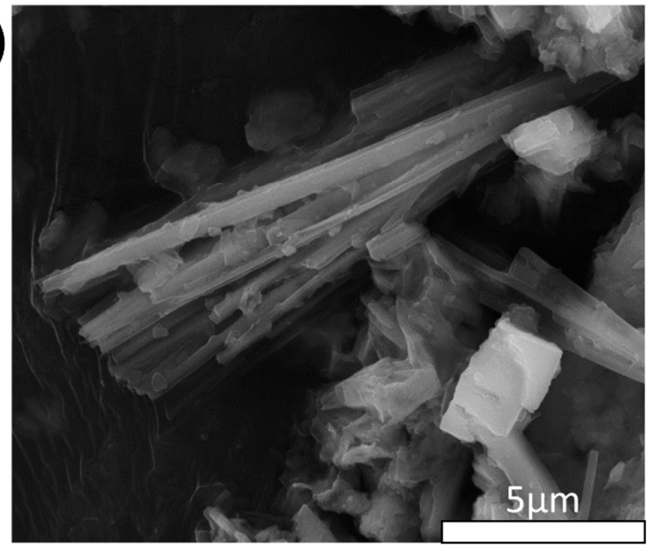

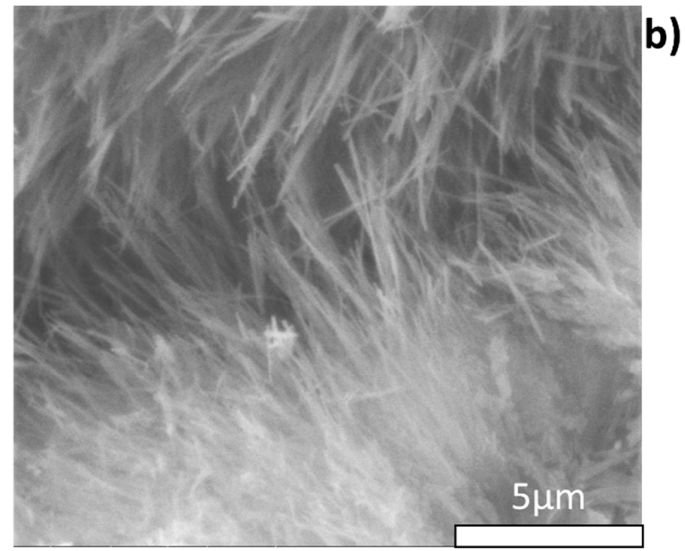

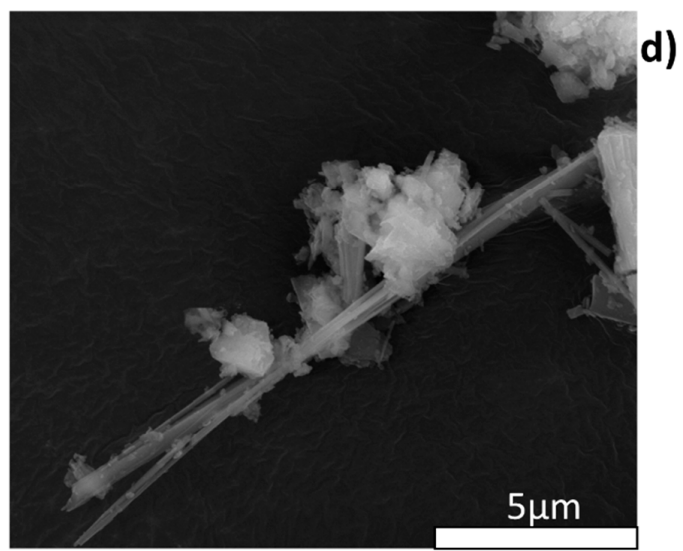

Figure 6. Gallery of SEM image of diagenetic mordenite. (a,b) Mordenite from Ponza Island (Italy). Fibers show a typical asbestiform habit. (c,d) Mordenite from Lovelock (Nevada, USA). The fibers bundles tend to separate into thin and quite rigid fibrils.

Although Poona mordenite does not show an asbestos-like habit and its morphology differs from that of fibrous erionite as described by Mattioli [64], its airborne fibers can be deposited in the alveolar space, where they high aspect ratio and biodurability may lead to the "frustrate phagocytosis" [38]. Since macrophages range in diameter from $\sim 10$ to $20 \mu \mathrm{m}[37,39]$, they cannot completely engulf the long 
mordenite fibers (average length $>20 \mu \mathrm{m}$ ). This leads to incomplete (frustrated) phagocytosis, which is characterized by the activation of the respiratory burst and the production of ROS and cytokines responsible for adverse effects at the cellular and subcellular levels. [4,35-39,48].

The zeta potential of mordenite fibres, as well as erionite, displays values in the range -10 to $-35 \mathrm{mV}$. Such zeta potential values may affect several molecular and cellular biomechanics such as cross-talk and apoptosis mechanisms, fiber encapsulation by collagen and redox-activated iron-rich proteins, and the ROS generation $[48,50]$.

As demonstrated by dissolution tests, mordenite possesses a high biodurability similar to that of erionite. According to Gualtieri et al. [16] the biodurability of zeolites is strictly related to the Si/Al framework ratio. In particular, the zeolite framework dissolution rate decreasing with increasing $\mathrm{Si} / \mathrm{Al}$ ratio and zeolites such as erionite and mordenite with $\mathrm{Si} / \mathrm{Al}$ ratio $>3$, show little to null dissolution in an acid environment [69]. Given the close link between biodurability and biopersistence, mordenite fibers are expected to persist and accumulate in the lower respiratory tract after being inhaled. As reported by several studies, biopersistent fibers with a morphology similar to that of mordenite ( $\mathrm{L}>8 \mu \mathrm{m}$ and $\mathrm{W}<0.25 \mu \mathrm{m}$ ) are able to trigger a chronic inflammatory process and related adverse effects [36-38].

For both fibrous erionite and mordenite, iron is not structural but associated with mineral particles at the surface of the fibers. According to the model described for fibrous erionite in Gualtieri et al. [66], iron-rich particles may dissolve during phagocytosis when the zeolite fibers are engulfed in the phago-lysosome sacks at $\mathrm{pH}=4-4.5$. Dissolution may leave a residue of iron atoms at specific sites anchored to the surface windows of the zeolite channels. These surface sites can be potential catalysts for ROS generation. Therefore, as with erionite, mordenite has the potential to induce oxidative stress $[36,70,71]$.

\section{Conclusions}

Among airborne pollutants, asbestos fibers have undoubtedly the worst reputation. However, recently, a new source of concern has arisen around fibrous zeolites and their potential health effect. Up to now, erionite is the only zeolite classified as carcinogen for humans by the IARC. In the present study we pointed out that, the fibrous mordenite has the same chemical-physical properties that are deemed to prompt adverse health effects. In particular, our investigations showed that mordenite, as with erionite, can display an asbestos-like shape and its fibers can be released as airborne particulate of breathable size. As demonstrated by the zeta potential analyses, the surface activity of mordenite is similar to erionite. Moreover, iron of mordenite is not structural but associated with secondary phases at the zeolite surface. The surface properties of fibrous mordenite, during fiber phagocytosis, may indirectly induce the formation of ROS with cyto-genotoxic effects. Based on the results of our dissolution tests is expected that mordenite is biodurable similar to erionite in the intracellular and extracellular environment. From this point of view, fibrous mordenite can be considered as a potential health hazard similar to fibrous erionite.

Currently, one of the main deposits of mordenite-rich exploded for industrial applications is the St. Cloud's Rome mordenite (a zeolite mineral) deposit in Rome, Oregon, in Malheur County (USA). Furthermore, mordenite occurs as the main phase in the zeolitized rocks of several countries such as Italy, Greece, Japan, and India. In this context, the implementation of a national/international policy for the elimination of potential exposure to dust containing mordenite fibers generated during extraction and grinding, as well as production and the use of material contains mordenite, should be taken into consideration by public authorities.

For a definitive and complete understanding of the potential toxicity of fibrous mordenite, in vitro toxicity test and animal carcinogenicity studies should be performed and compared to the outcome of our study to stimulate a critical evaluation and a possible reclassification of mordenite by the IARC. 
Funding: This research was conducted under the project "Fibers a Multidisciplinary Mineralogical, Crystal-Chemical and Biological Project to Amend the Paradigm of Toxicity and Cancerogenicity of Mineral Fibers" (PRIN: PROGETTI DI RICERCA DI RILEVANTE INTERESSE NAZIONALE-Bando 2017-Prot. 20173X8WA4). The study was further supported in part by the project "CCIAARE-Attuazione di un progetto di accompagnamento delle imprese nell'ambito del progetto PID impresa 4.0" financed by the Camera di Commercio di Reggio Emilia (Italy).

Acknowledgments: Author warmly thank all the collaborators who contributed to the experimental part of the work: Alessandro Zoboli, Tommaso Giovanardi, Riccardo Fantini and Ilaria Baldini.

Conflicts of Interest: The author declares no conflict of interest. The funders had no role in the design of the study; in the collection, analyses, or interpretation of data; in the writing of the manuscript, or in the decision to publish the results.

\section{References}

1. Sisko, A.; Boffetta, P. Occupational Cancers; Springer Nature: London, UK, 2020; p. 640.

2. IARC (International Agency for Research on Cancer). Asbestos (chrysotile, amosite, crocidolite, tremolite, actinolite, and anthophyllite). IARC Monogr. Eval. Carcinog Risks Hum. C 2012, 100, 219-309.

3. Gualtieri, A.F. Mineral fibre-based building materials and their health hazards. In Toxicity of Building Materials; Woodhead Publishing: Cambridge, UK, 2012; pp. 166-195.

4. Carbone, M.; Kanodia, S.; Chao, A.; Miller, A.; Wali, A.; Weissman, D.; Adjei, A.; Baumann, F.; Boffetta, P.; Buck, B.; et al. Consensus Report of the 2015 Weinman International Conference on Mesothelioma. J. Thorac. Oncol. 2016, 11, 1246-1262. [CrossRef] [PubMed]

5. Middendorf, P.; Zumwalde, R.; Castellan, R.; Harper, M.; Wallace, W.; Stayner, L.; Castranova, V.; Hearl, F.; Sullivan, P.; Wallace, W.; et al. Asbestos Fibers and Other Elongate Mineral Particles: State of the Science and Roadmap for Research; NIOSH Current Intelligence Bulletin 62; National Institute for Occupational Safety and Health (NIOSH): Cincinnati, OH, USA, 2011; p. 174.

6. Baumann, F.; Buck, B.J.; Metcalf, R.V.; McLaurin, B.T.; Merkler, D.J.; Carbone, M. The Presence of Asbestos in the Natural Environment is Likely Related to Mesothelioma in Young Individuals and Women from Southern Nevada. J. Thorac. Oncol. 2015, 10, 731-737. [CrossRef] [PubMed]

7. Larson, T.C.; Antao, V.C.; Bove, F.J. Vermiculite worker mortality: Estimated effects of occupational exposure to Libby amphibole. J. Occup. Environ. Med. 2010, 52, 555-560. [CrossRef]

8. Comba, P.; Gianfagna, A.; Paoletti, L. Pleural mesothelioma cases in Biancavilla are related to a new fluoro-edenite fibrous amphibole. Arch. Environ. Health 2003, 58, 229-232. [CrossRef]

9. Di Giuseppe, D.; Harper, M.; Bailey, M.; Erskine, B.; Della Ventura, G.; Ardith, M.; Pasquali, L.; Tomaino, G.; Ray, R.; Mason, H.; et al. Characterization and assessment of the potential toxicity/pathogenicity of fibrous glaucophane. Environ. Res. 2019, 178, 108723. [CrossRef]

10. Petriglieri, J.R.; Laporte-Magoni, C.; Salvioli-Mariani, E.; Tomatis, M.; Gazzano, E.; Turci, F.; Cavallo, A.; Fubini, B. Identification and Preliminary Toxicological Assessment of a Non-Regulated Mineral Fiber: Fibrous Antigorite from New Caledonia. Environ. Eng. Geosci. 2020, 26, 89-97. [CrossRef]

11. Groppo, C.; Tomatis, M.; Turci, F.; Gazzano, E.; Ghigo, D.; Compagnoni, R.; Fubini, B. Potential toxicity of nonregulated asbestiform minerals: Balangeroite from the western Alps. Part 1: Identification and characterization. J. Toxicol. Environ. Health A 2005, 68, 1-19. [CrossRef]

12. Carbone, M.; Yang, H. Molecular pathways: Targeting mechanisms of asbestos and erionite carcinogenesis in mesothelioma. Clin. Cancer Res. 2012, 18, 598-604. [CrossRef]

13. Mattioli, M.; Giordani, M.; Arcangeli, P.; Valentini, L.; Boscardin, M.; Pacella, A.; Ballirano, P. Prismatic to asbestiform offretite from Northern Italy: Occurrence, morphology and crystal-chemistry of a new potentially hazardous zeolite. Minerals 2018, 8, 69. [CrossRef]

14. Zoboli, A.; Di Giuseppe, D.; Baraldi, C.; Gamberini, M.C.; Malferrari, D.; Urso, G.; Gualtieri, M.L.; Bailey, M.; Gualtieri, A.F. Characterisation of fibrous ferrierite in the rhyolitic tuffs at Lovelock, Nevada, USA. Mineral. Mag. 2019, 83, 577-586. [CrossRef]

15. Carbone, M.; Emri, S.; Dogan, A.U.; Steele, I.; Tuncer, M.; Pass, H.I.; Baris, Y.I. A mesothelioma epidemic in Cappadocia: Scientific developments and unexpected social outcomes. Nat. Rev. Cancer 2007, 7, 147-154. [CrossRef] [PubMed] 
16. Gualtieri, A.F.; Gandolfi, N.B.; Passaglia, E.; Pollastri, S.; Mattioli, M.; Giordani, M.; Ottaviani, M.F.; Cangiotti, M.; Bloise, A.; Barca, D.; et al. Is fibrous ferrierite a potential health hazard? Characterization and comparison with fibrous erionite. Am. Mineral. 2018, 103, 1044-1055. [CrossRef]

17. Tschernich, R.W. Zeolites of the World; Geoscience Press: Tucson, AZ, USA, 1992; p. 563.

18. Stephenson, D.J.; Fairchild, C.I.; Buchan, R.M.; Dakins, M.E. A fiber characterization of the natural zeolite, mordenite: A potential inhalation health hazard. Aerosol Sci. Technol. 1999, 30, 467-476. [CrossRef]

19. Passaglia, E. The Crystal Chemistry of Mordenites. Contrib. Mineral. Petrol. 1975, 50, 65-77. [CrossRef]

20. Meier, W.M. The crystal structure of mordenite (ptilolite). Z. Krist. 1961, 115, 439-450. [CrossRef]

21. How, D.C.L. On mordenite, a new mineral from the trap of Nova Scotia. J. Chem. Soc. 1984, 17, 100-104.

22. Simoncic, P.; Armbruster, T. Peculiarity and defect structure of the natural and synthetic zeolite mordenite: A single-crystal X-ray study. Am. Mineral. 2004, 89, 421-431. [CrossRef]

23. Martucci, A.; Sacerdoti, M.; Cruciani, G.; Dalconi, C. In situ time resolved synchrotron powder diffraction study of mordenite. Eur. J. Mineral. 2003, 15, 485-493. [CrossRef]

24. Passaglia, E.; Sheppard, R.A. The crystal chemistry of zeolites. In Natural Zeolites: Occurrence, Properties Application; Bish, D.L., Ming, D.W., Eds.; Mineralogical Society of America and Geochemical Society: Washington, DC, USA, 2001; pp. 69-116.

25. Zhang, L.; Xie, S.; Xin, W.; Li, X.; Liu, S.; Xu, L. Crystallization and morphology of mordenite zeolite influenced by various parameters in organic-free synthesis. Mater. Res. Bull. 2011, 46, 894-900. [CrossRef]

26. Passaglia, E.; Artioli, G.; Gualtieri, A.; Carnevali, R. Diagenetic mordenite from Ponza, Italy. Eur. J. Mineral. 1995, 7, 429-438. [CrossRef]

27. Godelitsas, A.; Gamaletsos, P.; Roussos-Kotsis, M. Mordenite-bearing tuffs from Prassa quarry, Kimolos Island, Greece. Eur. J. Mineral. 2010, 22, 797-811. [CrossRef]

28. Negishi, T. Mordenite in the tuffs of the Shirasawa District, Miyagl Prefecture. J. Jpn. Assoc. Mineral. Petrol. Econ. Geol. 1972, 67, 29-34. [CrossRef]

29. IARC (International Agency for Research on Cancer). Silica, some silicates, coal dust and para-aramid fibrils. IARC Monogr. Eval. Carcinog. Risks Hum. C 1997, 68, 307-337.

30. IARC Monographs on the IDENTIFICATION of CARCINOGENIC Hazards to Humans. Available online: https://monographs.iarc.fr/wp-content/uploads/2019/07/Preamble-2019.pdf (accessed on 2 August 2020).

31. Suzuki, Y. Carcinogenic and fibrogenic effects of zeolites: Preliminary observations. Environ. Res. 1982, 27, 433-445. [CrossRef]

32. Suzuki, Y.; Kohyama, N. Malignant mesothelioma induced by asbestos and zeolite in the mouse peritoneal cavity. Environ. Res. 1984, 35, 277-292. [CrossRef]

33. Tátrai, E.; Bácsy, E.; Kárpáti, J.; Ungváry, G. On the examination of the pulmonary toxicity of mordenite in rats. Pol. J. Occup. Med. Environ. Health 1992, 5, 237-243.

34. Adamis, Z.; Tátrai, E.; Honma, K.; Six, É.; Ungváry, G. In Vitro and in Vivo Tests for Determination of the Pathogenicity of Quartz, Diatomaceous Earth, Mordenite and Clinoptilolite. Ann. Occup. Hyg. 2000, 44, 67-74. [CrossRef]

35. Gualtieri, A.F. Towards a quantitative model to predict the toxicity/pathogenicity potential of mineral fibers. Toxicol. Appl. Pharm. 2018, 361, 89-98. [CrossRef]

36. Carbone, M.; Adusumilli, P.S.; Alexander, H.R., Jr.; Baas, P.; Bardelli, F.; Bononi, A.; Bueno, R.; Felley-Bosco, E.; Galateu-Salle, F.; Jablons, D.; et al. Mesothelioma: Scientific clues for prevention, diagnosis, and therapy. CA-Cancer J. Clin. 2019, 69, 402-429. [CrossRef]

37. Stanton, M.F.; Layard, M.; Tegeris, A.; Miller, E.; May, M.; Morgan, E.; Smith, A. Relation of particle dimension to carcinogenicity in amphibole asbestoses and other fibrous minerals. J. Natl. Cancer Inst. 1981, 67, 965-975. [PubMed]

38. Donaldson, K.; Murphy, F.A.; Duffin, R.; Poland, C.A. Asbestos, carbon nanotubes and the pleural mesothelium: A review of the hypothesis regarding the role of long fibre retention in the parietal pleura, inflammation and mesothelioma. Part. Fibre Toxicol. 2010, 7, 5. [CrossRef] [PubMed]

39. Di Giuseppe, D.; Zoboli, A.; Vigliaturo, R.; Gieré, R.; Bonasoni, M.P.; Sala, O.; Gualtieri, A.F. Mineral fibres and asbestos bodies in human lung tissue: A case study. Minerals 2019, 9, 618. [CrossRef]

40. Padmore, T.; Stark, C.; Turkevich, L.A.; Champion, J.A. Quantitative analysis of the role of fiber length on phagocytosis and inflammatory response by alveolar macrophages. BBA-Gen. Subj. 2017, 1861, 58-67. [CrossRef] [PubMed] 
41. Deng, Z.J.; Liang, M.L.; Tóth, I.; Monteiro, M.J.; Michin, R.F. Molecular interaction of poly (acrylic acid) gold nanoparticles with human fibrinogen. ACS Nano 2012, 6, 8962-8969. [CrossRef]

42. Harris, R.L.; Timbrell, V. Relation of alveolar deposition to the diameter and length of glass fibres. In Proceedings of the Inhaled Particles IV International Symposium Organized by the British Occupational Hygiene Society, Edinburgh, UK, 22-26 September 1977; Pergamon Press: Oxford, UK, 1977; p. 411.

43. Yeh, H.C.; Phalen, R.F.; Raabe, O.G. Factors influencing the deposition of inhaled particles. Environ. Health Perspect. 1976, 15, 147-156. [CrossRef]

44. Aust, A.E.; Cook, P.M.; Dodson, R.F. Morphological and chemical mechanisms of elongated mineral particle toxicities. J. Toxicol. Environ. Health Part B 2011, 14, 40-75. [CrossRef]

45. Bonneau, L.; Suquet, H.; Malard, C.; Pezerat, H. Studies on surface properties of asbestos: I. active sites on surface of chrysotile and amphiboles. Environ. Res. 1986, 41, 251-267. [CrossRef]

46. Turci, F.; Tomatis, M.; Lesci, I.G.; Roveri, N.; Fubini, B. The iron-related molecular toxicity mechanism of synthetic asbestos nanofibres: A model study for high-aspect-ratio nanoparticles. Chem. Eur. J. 2011, 17, 350-358. [CrossRef]

47. Hardy, J.A.; Aust, A.E. Iron in asbestos chemistry and carcinogenicity. Chem. Rev. 1995, 95, 97-118. [CrossRef]

48. Gualtieri, A.F.; Andreozzi, G.B.; Tomatis, M.; Turci, F. Iron from a geochemical viewpoint. Understanding toxicity/pathogenicity mechanisms in iron-bearing minerals with a special attention to mineral fibers. Free Radic. Bio. Med. 2019, 133, 21-37. [CrossRef] [PubMed]

49. Pollastri, S.; Gualtieri, A.F.; Ignatyev, K.; Strafella, E.; Pugnaloni, A.; Croce, A. Stability of mineral fibres in contact with human cell cultures. An in situ $\mu$ XANES, $\mu$ XRD and XRF iron mapping study. Chemosphere 2016, 164, 547-557. [CrossRef] [PubMed]

50. Pollastri, S.; Gualtieri, A.F.; Gualtieri, M.L.; Hanuskova, M.; Cavallo, A.; Gaudino, G. The zeta potential of mineral fibres. J. Hazard. Mater. 2014, 276, 469-479. [CrossRef] [PubMed]

51. Gualtieri, A.F.; Pollastri, S.; Gandolfi, N.B.; Gualtieri, M.L. In vitro acellular dissolution of mineral fibres: A comparative study. Sci. Rep. 2018, 8, 7071. [CrossRef] [PubMed]

52. Bernstein, D.M.; Chevalier, J.; Smith, P. Comparison of Calidria chrysotile asbestos to pure tremolite: Final results of the inhalation biopersistence and histopathology examination following short-term exposure. Inhal. Toxicol. 2005, 17, 427-449. [CrossRef] [PubMed]

53. Sukheswala, R.N.; Avasia, R.K.; Gangopadhyay, M. Zeolites and associated secondary minerals in the Deccan Traps of Western India. Mineral. Mag. 1974, 39, 658-671. [CrossRef]

54. National Institute of Mental Health. ImageJ. Available online: https://imagej.nih.gov/ij/ (accessed on 14 March 2020).

55. Gualtieri, A.F.; Mossman, B.T.; Roggli, V.L. Towards a general model for predicting the toxicity and pathogenicity of minerals fibres. In Mineral Fibres: Crystal Chemistry, Chemical-Physical Properties, Biological Interaction and Toxicity; Gualtieri, A.F., Ed.; European Mineralogical Union: London, UK, 2017; pp. 501-526.

56. Heyder, J.; Gebhart, J.; Rudolf, G.; Schiller, C.F.; Stahlhofen, W. Deposition of particles in the human respiratory tract in the size range $0.005-15 \mu \mathrm{m}$. J. Aerosol Sci. 1986, 17, 811-825. [CrossRef]

57. French, C.A. Respiratory tract. In Cytology: Diagnostic Principles and Clinical Correlates; Cibas, E.S., Ducatman, B.S., Eds.; Elsevier Saunders: Philadelphia, PA, USA, 2009; pp. 65-103.

58. Gonda, I.; Abd El Khalik, A.F. On the calculation of aerodynamic diameters of fibers. Aerosol. Sci. Technol. 1985, 4, 233-238. [CrossRef]

59. Gu, Y.; Li, D. The $\zeta$-potential of glass surface in contact with aqueous solutions. J. Colloid Interface Sci. 2000, 226, 328-339. [CrossRef]

60. Sze, A.; Erickson, D.; Ren, L.; Li, D. Zeta-potential measurement using the Smoluchowski equation and the slope of the current-time relationship in electroosmotic flow. J. Colloid Interface Sci. 2003, 261, 402-410. [CrossRef]

61. Stern, O. The theory of the electrolytic double-layer. Z. Elektrochem. 1924, 30, 508-516.

62. Gualtieri, A.F.; Lusvardi, G.; Zoboli, A.; Di Giuseppe, D.; Gualtieri, M.L. Biodurability and release of metals during the dissolution of chrysotile, crocidolite and fibrous erionite. Environ. Res. 2019, 171, 550-557. [CrossRef] [PubMed]

63. WHO (World Health Organization). Determination of Airborne Fibre Number Concentrations. Available online: http://apps.who.int/iris/bitstream/10665/41904/1/9241544961.pdf (accessed on 4 August 2020). 
64. Mattioli, M.; Giordani, M.; Dogan, M.; Cangiotti, M.; Avella, G.; Giorgi, R.; Dogan, U.A.; Ottaviani, M.F. Morpho-chemical characterization and surface properties of carcinogenic zeolite fibers. J. Hazard. Mater. 2016, 306, 140-148. [CrossRef] [PubMed]

65. Croce, A.; Allegrina, M.; Rinaudo, C.; Gaudino, G.; Yang, H.; Carbone, M. Numerous iron-rich particles lie on the surface of erionite fibers from Rome (Oregon, USA) and Karlik (Cappadocia, Turkey). Microsc. Microanal. 2015, 21, 1341-1347. [CrossRef]

66. Gualtieri, A.F.; Gandolfi, N.B.; Pollastri, S.; Pollok, K.; Langenhorst, F. Where is iron in erionite? A multidisciplinary study on fibrous erionite-Na from Jersey (Nevada, USA). Sci. Rep. 2016, 6, 37981. [CrossRef]

67. Ballirano, P.; Andreozzi, G.B.; Dogan, M.; Dogan, A.U. Crystal structure and iron topochemistry of erionite-K from Rome, Oregon, USA. Am. Mineral. 2009, 94, 1262-1270. [CrossRef]

68. Matassa, R.; Familiari, G.; Relucenti, M.; Battaglione, E.; Downing, C.; Pacella, A.; Cametti, G.; Ballirano, P. A deep look into erionite fibres: An electron microscopy investigation of their self-assembly. Sci. Rep. 2015, 5, 16757. [CrossRef]

69. Hartman, R.L.; Fogler, H.S. Understanding the dissolution of zeolites. Langmuir 2007, 23, 5477-5484. [CrossRef]

70. Urano, N.; Yano, E.; Evans, P.H. Reactive oxygen metabolites produced by the carcinogenic fibrous mineral erionite. Environ. Res. 1991, 54, 74-81. [CrossRef]

71. Pacella, A.; Cremisini, C.; Nardi, E.; Montereali, M.R.; Pettiti, I.; Giordani, M.; Mattioli, M.; Ballirano, P. Different erionite species bind iron into the structure: A potential explanation for fibrous erionite toxicity. Minerals 2018, 8, 36. [CrossRef]

(C) 2020 by the author. Licensee MDPI, Basel, Switzerland. This article is an open access article distributed under the terms and conditions of the Creative Commons Attribution (CC BY) license (http://creativecommons.org/licenses/by/4.0/). 